\title{
ANALISIS KESALAHAN MAHASISWA PGSD DALAM MENYELESAIKAN SOAL PEMECAHAN MASALAH MATEMATIS BERDASARKAN GEORGE POLYA
}

\author{
Nia Kania \\ Program Studi Pendidikan Matematika, Universitas Majalengka \\ Jl. Universitas Majalengka No.1 \\ kaniasoehenda@gmail.com
}

\begin{abstract}
Penelitian ini bertujuan untuk mengetahui (1) Faktor-faktor apa sajakah yang menjadi penyebab mahasiswa melakukan kesalahan-kesalahan dalam setiap langkah pemecahan masalah George Polya; (2) Bagaimana cara mengatasi kesalahan mahasiswa dalam pemecahan masalah matematis? Subjek penelitian ini adalah mahasiswa semester V pada Program Studi Guru Sekolah Dasar Universitas Majalengka. Instrumen yang digunakan dalam penelitian ini berupa tes kemampuan pemecahan masalah matematis dan wawancara serta observasi.. Berdasarkan analisis data hasil penelitian, diperoleh kesimpulan bahwa (1) Faktor yang menyebabkan kesulitan mahasiswa yaitu (a) masih kurangnya pemahaman mahasiswa dengan materi yang diajarkan; (b) mahasiswa belum menguasai materi bangun ruang; (c) kurangnya daya ingat mahasiswa untuk mengingat kembali materi yang telah disampaikan; (2) Langkah-langkah penyelesaian yang ditemukan yaitu (a) membaca dan memahami; (b) menggali serta menuliskan informasi yang dapat dimunculkan dari soal; (c) memilih strategi penyelesaian; (d) mengerjakannya serta meneliti kembali jawabannya.
\end{abstract}

Keywords: Analisis Kesalahan, Pemecahan Masalah Matematis, Goerge Polya

\section{PENDAHULUAN}

Permasalahan

matematika berbentuk masalah penerapan atau aplikasi menurut Suharsimi Arikunto, mahasiswa dituntut memiliki kemampuan menyeleksi atau memilih suatu abstraksi tertentu (konsep, hukum, dalil, aturan) secara tepat dan benar untuk diterapkan dalam situasi baru, dengan demikian untuk dapat menyelesaikan masalah penerapan dibutuhkan kemampuan yang kompleks meliputi pengetahuan, pemahaman dan kemampuan aplikasi. Menurut Hudoyo (2001) mengatakan bahwa "Problem in mathematics is not just a task or question to be answered by the 
students but has a special meaning as well as involve two requirements: (i) must be understood by students and challenging, (ii) task can not be solved by a procedure already knew (non-routine)".

Tahap pokok atau penting dalam memecahkan masalah yang sudah diterima luas, dan ini bersumber dari buku George Polya tahun 1945 berjudul How to Solve It. Keempat langkah tersebut adalah sebagai berikut. 1) Memahami soal/masalah selengkap mungkin. Untuk dapat melakukan tahap 1 dengan baik, maka perlu latihan untuk memahami masalah baik berupa soal cerita maupun soal non-cerita. 2) Memilih rencana penyelesaian dari beberapa alternatif yang mungkin. 3) Menerapkan rencana dengan tepat, cermat dan benar. 4) Memeriksa jawaban apakah sudah benar, lengkap, jelas dan argumentatif (beralasan).

Pada umumnya dalam menyelesaikan masalah matematis mahasiswa melakukan kesalahan dalam langkah pertama, kedua dan seterusnya. Dengan demikian berarti dapat terjadi serangkaian kesalahan sehingga kesalahan pertama menjadi penyebab kesalahan kedua dan seterusnya, sehingga diperlukan langkah-langkah yang sistematis agar proses penyelesaiannya mudah dan terarah, salah satunya dengan langkah penyelesaian masalah menurut Polya

Kesulitan dari sebagian besar masalah matematika tidak terletak pada perhitungan, tetapi lebih pada pengetahuan bagaimana memperjelas masalah sehingga masalah tersebut dapat dipecahkan, mahasiswa tidak melakukan langkah-langkah penyelesaian yang sistematis, mahasiswa selalu ingin mendapatkan hasil akhir secara langsung tanpa membuat model matematika yang sederhana dari soal.

Banyak mahasiswa yang masih mengalami kendala dalam pembelajaran matematika berkisar pada karakteristik matematika yang abstrak, masalah media. Adapun menurut Subanji dan Mulyoto (dalam Rosita, 2007: 15) jenis-jenis kesalahan yang dilakukan mahasiswa dalam menyelesaikan soal matematika antara lain sebagai berikut. (1) Kesalahan konsep; (2) Kesalahan menggunakan data; (3) Kesalahan interpretasi bahasa; (4) Kesalahan teknis; (5) Kesalahan penarikan kesimpulan.

\section{KAJIAN PUSTAKA}

Analisis merupakan penyelidikan terhadap suatu peristiwa (karangan, perbuatan dan sebagainya) untuk mengetahui keadaan yang sebenarnya (sebab- musabab, duduk perkaranya dan sebagainya); penguraian suatu pokok atas berbagai bagiannya dan penelaahan bagian itu sendiri serta hubungan antar bagian untuk memperoleh pengertian yang tepat dan pemahaman artikel seluruhan (KamusBesar Bahasa Indonesia KEMDIKNAS). Menurut Murwati (dalam Rosita, 2007: 16), kesalahan-kesalahan yang dilakukan mahasiswa dalam mengerjakan soal-soal matematika dapat didefinisikan menjadi beberapa aspek antara lain:

(1) Aspek bahasa

Aspek Bahasa merupakan kesulitan 
dan kekeliruan mahasiswa dalam menafsirkan kata-kata atau simbolsimbol dan Bahasa yang digunakan dalam matematika.

(2) Aspekimajinasi

Aspek imajinasi adalah kesulitan dan kekeliruan mahasiswa dalam imajinasi ruang (spasial) dalam dimensi-dimensi tiga yang berakibat salah dalam mengerjakan soal-soal matematika.

(3) Aspek prasyarat Aspek prasyarat merupakan kesalahan dan kekeliruan mahasiswa dalam mengerjakan soal matematika karena bahan pelajaran yang sedang dipelajari mahasiswa belum dikuasai.

(4) Aspek tanggapan

Aspek tanggapan merupakan kekeliruan dalam penafsiran atautanggapan mahasiswa terhadap konsepsi, rumus, dan dalil-dalil matematika dalam mengerjakan soal matematika.

(5) Aspek terapan

Aspek terapan merupakan kekeliruan mahasiswa dalam menerapkan rumus dan dalil-dalil matematika dalam mengerjakan soal-soal matematika.

\section{A. Jenis Kesalahan}

Dalampembelajaranmatematika, mahasiswa seringkalimelakukan kesalahan-kesalahan, khususnya kesalahan dalam mengerjakan soal. Kesalahan tersebut dapat disebabkan rendahnya pemahaman konsep matematika mahasiswa, ketidaktelitian mahasiswa dalam menghitung, dan lain sebagainya.

Jika ditinjau dari tahap-tahap pemecahan masalah matematika yang diungkap oleh Polya (1973, 1981), maka kesalahan-kesalahan tersebut dapat dikelompokkan menjadi empat jenis yaitu kesalahan-kesalahan pada waktu:

(a) memahami masalah,

(b) membuat rencana pemecahan masalah,

(c) melaksanakan rencana pemecahan masalah, atau

(d) melihat kembali penyelesaian masalah.

Sebagai contoh, mahasiswa salah memilih strategi pemecahan masalah. Kesalahan ini mungkin disebabkan karena hal-hal sebagai berikut:

1. Mahasiswa tidak dapat mengidentifikasi apa yang diketahui dan apa yang ditanyakan dari masalah. Misalnya yang ditanyakan A, tetapi dalam pikiran mahasiswa $\mathrm{B}$, sehingga strategi yang dipilih adalah strategi menuju B. Akibatnya mahasiswa salah dalam memilih strategi pemecahan masalah.

2. Mahasiswa tidak dapat mengidentifikasi konsep apa yang ada dalam masalah sehingga ia salah memilih konsep yang berakibat salah membuat strategi pemecahan masalah.

3. Mahasiswa mengetahui konsep yang ada dalam masalah. Akan tetapi, ia tidak memiliki skema mengenai konsep tersebut sehingga ia tidak dapat membuat strategi yang sesuai. 
4. Mahasiswa mengetahui apa yang diketahui, apa yang ditanyakan, konsep apa yang ada dalam masalah dan memilikinya. Akan tetapi, ia tidak dapat mensintesisnya menjadi suatu rencana pemecahan masalah. Ini disebabkan karena mahasiswa belum memiliki skema pemecahan masalah yang sesuai. Ketidakadaan skema ini dapat disebabkan oleh mahasiswa belum pernah menyelesaikan masalah yang serupa dengan masalah yang dihadapi sebelumnya.

\section{B. Indikator Jenis Kesalahan}

Dalam memecahkan masalah dalam matematika banyak mahasiswa yang masih mengalami kendala, Kendala yang terjadi dalam pembelajaran matematika berkisar pada karakteristik matematika yang abstrak, masalah media, masalah peserta didik atau guru. Menurut Subanji dan Mulyoto (dalam Rosita,2007:15) jenis-jenis kesalahan yang dilakukan mahasiswa dalam menyelesaikan soal matematika antara lain sebagai berikut.

(1) Kesalahankonsep, indikatornyaadalah:

(a) Kesalahan menentukan teorema atau rumus untuk menjawab suatu masalah;

(b) Penggunaan teorema atau rumus oleh mahasiswa tidaksesuai dengan kondisi prasyarat berlakunya rumus tersebut atau tidak menuliskan teorema.

(2) Kesalahan menggunakan data, indikatornya adalah: (a) Tidak menggunakan data yang seharusnya dipakai;

(b) Kesalahan memasukkan data ke variabel;

(c) Menambah data yang tidak diperlukan dalam menjawab suatu masalah.

(3) Kesalahan interpretasi bahasa, indikatornya adalah:

(a) Kesalahan dalam menyatakan bahasa sehari-hari dalam bahasa matematika;

(b) Kesalahan menginterpretasikan symbol-simbol, grafik, dan table ke dalam Bahasa matematika.

(4) Kesalahanteknis, indikatornya adalah:

(a) Kesalahan perhitungan atau komputasi;

(b) Kesalahan memanipulasi operasialjabar.

(5) Kesalahanpenarikankesimpulan, indikatornya adalah:

(a) Melakukan penyimpulan tanpa alasan pendukung yang benar;

(b) Melakukan penyimpulan pernyataan yang tidak sesuai dengan penalaran logis.

\section{Pemecahan Masalah Matematis}

MenurutRobert L. Solso (Ratnasari, 2014), pemecahan masalah adalah suatu pemikiranyang terarah secaralangsung untuk menemukan solusi atau jalan keluar untuk suatu masalah yang spesifik. Sedangkan Siwono (2008) berpendapat bahwa pemecahan masalah adalah suatu prosesatau upaya individu untuk merespon atau mengatasi halangan 
atau kendala ketika suatu jawaban atau metode jawaban belum tampak jelas. Dengan demikian pemecahan masalah adalah proses berpikir individu secara terarah untuk menentukan apa yang harus dilakukandalam mengatasisuatu masalah.

Kemudian Sakshaug et al. (2002) menambahkan bahwa pemecahan masalah harus meliputi beberapa tahap sebagai berikut : describe the mathematical problem-solving experience as something that 'encompasses the acts of exploring, reasoning, strategizing, estimating, conjecturing, testing, explaining and proving. Pengalaman matematika pemecahan masalah sebagai sesuatu yang meliputi tindakan mengeksplorasi, penalaran, strategi, memperkirakan, conjecturing, pengujian, menjelaskan dan membuktikan.

Ellison (2009) menyatakanbahwa melalui latihan rutin dan strategi pengajaran keterampilan pemecahan masalah akan meningkatkan kemampuan pemecahan masalah padamahasiswa.

Sebagai pedoman penyusunan soal pemecahan masalah, criteria soal pemecahan masalah menurut Fungdan Roland

(Sugiman,Kusumah,\&Subanjar,2008)adal ah sebagai berikut; 1)Masalah hendaknya memerlukan lebih dari satu langkah dalam menyelesaikannya;2) Masalah hendaknya dapat diselesaikan dengan lebih dari satucara/metode; 3) Masalah hendaknya menggunakan bahasa yang jelas dan tidak menimbulkan salah tafsir;4) Masalah hendaknya menarik(menantang) serta relevan dengan kehidupan mahasiswa; dan
5) Masalah hendaknya mengandung nilai (konsep)matematik yangnyata sehingga masalah tersebut dapat meningkatkan pemahaman dan memperluas pengetahuan matematik amahasiswa.

\section{Langkah Pemecahan Masalah} Matematis

Langkah-langkah Goerge Polya, yang terdiri dari empat langkah utama yaitu: Understanding the problem, Devising a Plan, Carrying out the Plan, dan Looking Back dengan rincian sebagai berikut:

1) Memahami masalah (Understanding the Problem)

a. Problem apa yang dihadapi?

b. Apa yang diketahui?

c. Apa yang ditanya?

d. Apa kondisinya?

e. Bagaimana memilah kondisikondisi tersebut?

f. Tuliskan hal-hal itu, bila perlu buatlah gambar, gunakan simbol atau lambang yang sesuai.

2) Menyusun rencana pemecahannya (Devising a Plan)

Menemukan hubungan antara data dengan hal-hal yang belum diketahui, atau mengaitkan hal-hal yang mirip secara analogi dengan masalah. Proses ini diawali dengan proses pengenalan dan observasi kemudian dicari keteraturan dari pola masalah yang diberikan.

3) Melaksanakan rencana (Carrying out the Plan) 
Menjalankan rencana guna menemukan solusi dapat dilakukan dengan cara:

a. Melaksanakan strategi sesuai dengan yang telah direncanakan pada tahap sebelumnya.

b. Melakukan pemeriksaan pada setiap langkah yang dikerjakan.

c. Mengupayakan agar pekerjaan dilakukan secara akurat.

4) Memeriksa kembali (Looking Back)

5) Melakukan pemeriksaan kembali terhadap solusi yang didapat dilakukan dalam beberapa kegiatan berikut:

a. Periksa hasil pada masalah asal.

b. Interpretasikan solusi pada masalah asal. Apakah solusi yang dihasilkan masuk akal?

c. Apakah ada cara lain untuk menyelesaikan masalah tersebut?

d. Jika memungkinkan, tentukan masalah lain yang berkaitan atau masalah lain yang lebih umum dimana strategi yang digunakan dapat bekerja.

\section{E. Stategi Pemecahan Masalah \\ Matematis}

Pada saat guru menggunakan strategi ini, sebaiknya ditekankan bahwa penggunaan objek yang dicontohkan dapat diganti dengan satu model yang lebih sederhana, misalnya:

1. Membuat gambar atau diagram.

$\begin{array}{rrr}\text { Strategi ini } & \text { terkait dengan } \\ \text { pembuatan } & \text { sketsa } & \text { untuk }\end{array}$

mengungkapkan informasi yang terkandung dalam masalah sehingga hubungan antar komponen dalam masalah dapat terlihat dengan jelas. Penekanan ini perlu dilakukan bahwa gambar atau diagram yang dibuat tidak perlu sempurna, terlalu bagus atau terlalu aktual, yang penting bagian-bagian terpenting dari gambaritu dapat memperjelas masalah.

\section{Menemukan pola}

Kegiatan matematikayang
berkaitan dengan proses
menemukansuatu pola dari sejumlah data yang diberikan, Dapat mulai dilakukan melalui sekumpulan gambar atau bilangan. Kegiatanyang mungkindilakukan antara lain dengan mengobserva sisifat-sifat yang dimiliki bersamaoleh kumpulan gambaratau bilangan yangtersedia. Sebagai suatu strategi untuk pemecahan masalah, pencarian pola yang pada awalnya hanya dilakukan secara pasif melalui permasalahan yang dikeluarkan oleh guru, pada suatu saat keterampilan itu akan terbentuk dengan sendirinya sehingga pada saat menghadapi permasalahan tertentu, salah satu pertanyaan yang mungkin muncul pada benak seseorang antara lain adalah:"Adakah pola atau keteraturan tertentu yang mengaitkan tiap datayang diberikan?". Tanpa melalui latihan sangat sulitbagi seseorang untuk menyadari bahwa dalam permasalahan yang dihadapinya terdapat pola yang bias diungkap. 


\section{Membuat table}

Mengorganisasi data ke dalam sebuah tabel dapat membantu kita dalam mengungkapkan suatu pola tertentu serta dalam mengidentifikasi informasiyang tidak lengkap. Penggunaan table merupakan langkah yang sangat efisien untuk melakukan klasifikasi serta menyusun sejumlah besardata sehingga apabila muncul pertanyaan baru berkenaan dengan data tersebut, maka kita akan dengan mudah menggunakan data tersebut, sehingga jawaban pertanyaan tadi dapat diselesaikan dengan baik.

4. Memperhatikan semua kemungkinan secara sistematik

Strategi ini biasanya digunakan bersamaan dengan strategi mencari pola dan menggambar tabel. Dalam menggunakan strategi ini, kita tidak perlu memperhatikan keseluruhan kemungkinan yang bisa terjadi. Yang kita perhatikan adalah semua kemungkinan yang diperoleh dengan cara sistematik. Yang dimaksudsistematik disini misalnya dengan mengorganisasikan data berdasarkan kategori tertentu. Namun demikian, untuk masalah-masalah tertentu, mungkin kita harus memperhatikan semua kemungkinan yang bias terjadi.

5. Tebak dan periksa

$$
\text { Strategi menebak yang }
$$
dimaksudkan disini adalah menebak yang didasarkan pada alasan tertentu serta kehati-hatian. Selain itu, Untuk dapat melakukan tebakan dengan baikseseorang perlu memiliki pengalaman cukupyangberkaitan dengan permasalahanyang dihadapi

6. Bekerja mundur

Suatu masalah kadang-kadang disajikan dalam suatu cara sehingga yang diketahui itu sebenarnya merupakan hasil dari proses tertentu, sedangkan komponen yang ditanyakan merupakan komponen yang seharusnya muncul lebih awal. Penyelesaian masalah seperti ini biasanya dapat dilakukan dengan menggunakan strategi mundur.Dengan strategi ini, kita bergerak dari yang diinginkan lalu menyesuaikan dengan yang diketahui.

7. Menyelesaikan masalah yang lebih sederhana

$$
\begin{aligned}
& \text { Suatu masalah kadang lebih } \\
& \text { mudah diselesaikan bila kita } \\
& \text { membuatnya menjadi lebih sederhana. } \\
& \text { Cara ini dapat ditempuh dengan } \\
& \text { menyederhakan bentuk atau variabel. }
\end{aligned}
$$

8. Menggunakan penalaran langsung

Strategi ini berkaitan dengan penggunaan penalaran maupun penarikan kesimpulan yang sah atau valid dari berbagai informasi atau data yang ada.

9. Menggunakan kasus

Hampir mirip dengan strategi use a simpler problem, strategi ini menggunakan contoh atau kasus masalah untuk mendapatkan ide penyelesaian yang menyeluruh. Hal ini dapat ditempuh dengan mensubstitusi nilai pada variabel atau mengaplikasi 
variabel pada kejadian khusus.

10. Mengidentifikasi sub tujuan

Masalah tersebut lebih mudah ditangani bila dipecah menjadi beberapa submasalah, dalam hal ini sesuai banyak kemungkinan penyelesaian.

11. Menggunakan simetri

Sifat simetri amat membantu kita menyelesaikan masalah, contohnya ketika ingin menghitung luas daerah tertutup antara kurva sebuah fungsi kuadrat dan sumbu x. Namun kita juga harus melihat sifat simetri ini pada masalah-masalah lain yang tidak menunjukkan kesimetrian pada pernyataan masalahnya. Kejelian kita dibutuhkan untuk melihat adakah kesimetrian pada masalah, dapatkah sifat simetri dimunculkan, dan lainlain.

\section{METODOLOGI}

a. Populasi dan Sampel

Penelitian ini dilakukan di Universitas Majalengka pada Program Studi Guru Sekolah Dasar pada mata kuliah Pemecahan Masalah Matematika semester ganjil tahun ajaran 2017/2018.

Pengambilan data dari subjek dalam penelitian akan terus berlangsung sampai data yang diperoleh jenuh. Subjek dalam penelitian ini adalah mahasiswa calon guru Sekolah Dasar semester V.

b. Desain Penelitian

Penelitian ini menggunakan mix metode atau dinamakan penelitian campuran. Dimana peneliti ingin mengetahui kemampuan pemecahan

$\begin{array}{lrr}\text { masalah } & \text { mahasiswa } & \text { berdasarkan } \\ \text { pemecahan } & \text { masalah } & \text { matematis } \\ \text { berdasarkan } & \text { George } & \text { Polya. }\end{array}$

Menurutcreswell (2010: 5), penelitian campuran merupakan pendekatan penelitian yang mengkombinasikan antara penelitian kualitatif dengan penelitian kuantitatif.Agar diperoleh analisis yang tepat mengenai kesulitan mahasiswa dalam pemecahan masalah matematis, maka skema penelitian kali ini hanya sampai pada analisis kesulitan dan cara mengatasi kesulitannya, sedangkan tahapan peningkatan akan dilakukan pada waktu dan skema penelitian lain di tahun yang akan datang.

Pada penelitian ini, model penelitian yang digunakan adalah model concurrent embedded (campuran tidak berimbang), yang menggabungkan antara metode penelitian kualitatif dan kuantitatif dengan cara mencampur kedua metode tersebut secara tidak seimbang (Sugiyono, 2013: 537). Pada penelitian ini, metode kualitatif merupakan metode primer karena bobotnya lebih tinggi, dan metode kuantitatif merupakan metode sekunder.

Adapun langkah-langkah penelitian kombinasi model concurrent embedded dapat dilihat melalui gambar 1 di bawah ini: 
ISSN $2086-3918$

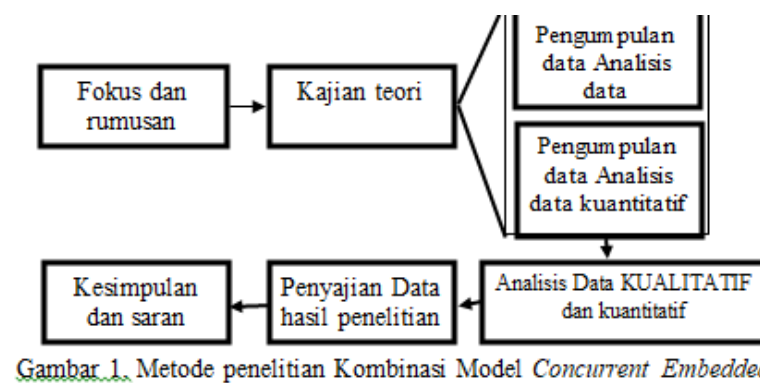

c. Alur Pengolahan Data

Data yang diperoleh dalam penelitian ini berupa data hasil catatan lapangan saat observasi, wawancara, dokumentasi dan tes. Kemudian data yang diperoleh dianalisis dalam beberapa tahap sebagai berikut:

Teknik analisis data yang digunakan dalampenelitianini melalui langkah-langkah menurutMiles dan Huberman dalam sugiyono (2007) terdiri atas:

1. Reduksi Data (data reduction)

$$
\text { Mereduksi data berarti }
$$
merangkum, memilih hal-hal pokok, memfokuskan pada hal-hal penting, dicari tema dan polanya dan polanya dan membuang yang tidak perlu. Data yang telah direduksi akan memberikan gambaran yang lebih jelas, dan mempermudah peneliti untuk melakukan pengumpulan data selanjutnya dan mencarinya bila perlu.

\section{Penyajian Data (data display)}

Setelah data direduksi, maka langkah selanjutnya adalah mendisplaykan data.Untuk data kualitatif, penyajian data bisa dilakukan dengan uraian singkat, bagan, hubungan antar kategori dan sejenisnya, sedangkan data kuantitatif di sajiakan dalam perhitungan statistik.

\section{Verifikasi (conclusion drawing)}

Data yang dianalisis dalam penelitian ini adalah hasil dari wawancara, observasi dan tes hasil belajar matematika mahasiswa.

\section{A. Pengecekan Keabsahan Data}

Agar hasil penelitian benar-benar dapat dipertanggung jawabkan, maka diadakan pemeriksann terhadap keabsahan data secara cermat sesuai dengan teknik yang ada. Menemukan keabsahan data ada 7 teknik pemeriksaan yaitu: (1) perpanjangan keikutsertaan, (2) ketekunan pengamatan, (3) triangulasi, (4) pengecekan sejawat, (5) kecukupan referensi, (6) kajian kasus negatif, (7) Pengecekan anggota.

Teknik pemeriksaan keabsahan data yang digunakan dalam penelitian ini, adalah sebagai berikut:

1. Ketekunan pengamatan

Ketekunan pengamatan dilakukan dengan cara peneliti mengadakan pengamatan secara teliti, rinci dan terus menerus selama prosesbelajar mengajar dan saat belajar mahasiswa. Sehingga selama pembelajaran berlangsung tercatat secara sistematis. Kegiatan ini diikuti dengan pelaksanaan wawancara secara intensif dan mendalam, Sehingga dapat terhindar dari hal-hal yang tidak diinginkan, seperti berdusta atau berpurapura.

2. Triangulasi data

$$
\text { Triangulasi adalah teknik }
$$
pemeriksaan keabsahan data yang 
memanfaatkan sesuatu yang lain diluar data itu untuk keperluan pengecekan atau sebagai pembanding terhadap dataitu. Triangulasi ini dilakukan dengan cara menggabungkan beberapa data-data yang telah terkumpul sehingga diperoleh data yang benar-benar absah dan objektif. "Denzin membedakan empat macam triangulasi sebagai teknik pemeriksaan yang memanfaatkan penggunaan sumber, metode, penyidik, dan teori."

Penelitian ini menggunakan teknik triangulasi dengan sumber, yang menurut Patton adalah "membandingkan dan mengecek balik derajat kepercayaan suatu informasi yang diperoleh melalui waktu dan alat yang berbeda dalam penelitian kualitatif. "Triangulasi dengan sumber dalam penelitian ini yaitu dengan mengecek balik derajat kepercayaan suatu informasi yang diperolehdari data hasil tes tertulis, data observasi dan data wawancara. Dengan cara membandingkan hasil pengamatan dengan hasil wawancara, membandingkan hasil tes dengan hasil wawancara, dan membandingkan hasil pengamatan dengan hasil tes.

\section{HASIL DAN PEMBAHASAN}

Setelah proses pemilihan subjek, didapat beberapa subjek untuk dijadikan sumber data dalam penelitian ini. Dari subjek yang diperoleh, peneliti memberikan soal penelitian untuk mendapatkan data berupa hasil jawaban subjek dalam menyelesaikan masalah matematika dan kesulitan-kesulitan yang dialami. Soal yang diberikan peneliti berupa soal non rutin yang mencakup indikator kesulitan belajar mahasiswa dan pemecahan masalah. Soal dan pedoman wawancara dibuat sendiri oleh peneliti dan sudah divaldasikan kepada validator, yaitu merupakan dosen Pendidikan Matematika dikampus peneliti. Peneliti memilih dosen tersebut dengan alasan karena peneliti menganggap bahwa dosen tersebut memahami tentang jenis penelitian yang dipiliholeh peneliti. Adapun soal yang digunakan dalam penelitian ini adalah sebagai berikut:

Sebuah wadah diisi tigabuah bola tenisyang berdiameter $6 \mathrm{~cm}$ seperti yang terlihat pad gambar di bawah ini. Hitunglah luas permukaan dust empat bola tenis fersebut! $\left(\pi=\frac{22}{7}\right)$

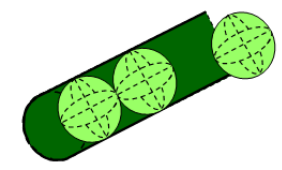

Gambar 4. 1. Soal Tes Pemecahan Masalah Matematika

Selain itu, peneliti juga membuat catatan mengenai aktifitas dan gerak tubuh yang dilakukan subjek saat mengerjakan soal penelitian. Selanjutnya peneliti melakukan wawancara satu persatu dengan melihat pedoman wawancara serta hasil jawaban subjek.

Dalam penelitian ini mendapatkan beberapa data dari subjek yaitu hasil jawaban subjek, hasil wawancara, dan catatan lapangan. Data tersebu takan dianalisis untuk menentukan kesulitan yang dialami subjek sehingga peneliti dapat menemukan langkah dan strategi dalam memecahkan masalah yang dialamI oleh subjek.

Setelah itu peneliti melakukan wawancara dengan subjek mengenai bagaimana penyelesaian yang digunakan 
dan kesulitan yang dialami. Peneliti melakukan wawancara satu persatu dengan beberapa subjek. Setelah wawancara selesai peneliti menuangkan hasil wawancara kedalam tulisan. Peneliti menganalisis hasil wawancara yang berkaitan dengan kesulitan yang dialami subjek.

\section{Reduksi Data}

Berikut hasil pengamatan dari 3 subjek yang telah mengerjakan soal non rutin dan telah diwawancarai.

\section{a) Subjek 1}

Dari hasil jawabans ubjek 1, subjek menulis kanapa yang diketahui dari soal, kemudian menulis kanapa saja yang ditanyakan dalam soal. Berikut penggalan jawaban subjek 1 pada lembar jawab.

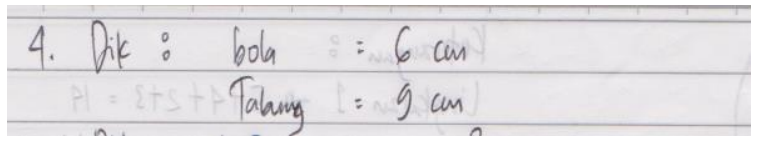

Gambar4.2 Hasil Jawaban Subjek 1

Dari gambar 4.2 dapat dilihat subjek 1 didalam lembar jawabnya menuliskan apa yang ia dapatkan dari soal berupa pengulangan soal. Hal ini berarti subjek telah membaca soal dan menentukan yang diketahui dalam soal tersebut, maka dengan demikian ia sudah mempunyai modal untuk melanjutkan mengerjakan soal dan bisa menghubungkan fakta-fakta yang ada sehingga mampu mencari apa yang diperlukan untuk memecahkan masalah pada soal.

Dalam catatan lapangan terhadap Subjek 1 terlihat bahwa dari pertama mendapat soal subjek 1 membaca soal dengan waktu yang lumayan lama yang diaselingi dengan menuliskan sesuatu pada lembar jawab dan menuliskan beberapa di lembar lain, ia juga terlihat sering memandangi lembar soal. Hal ini menunjukkan subjek 1 membaca soal terlebih dahulu sambal memahami soal dan mulai menuliskan apa yang bisa didapat dari soal untuk membuat rencana penyelesaian, kemudian dapat menentukan hal-hal yang dibutuhkan dalam proses pemecahan masalah.

Hasil wawancara dengan subjek 1 juga mendukung apa yang peneliti paparkan diatas. Berikut beberapa penggalan wawancara yang peneliti lakukan.

$\mathrm{P}$ : apakah sudah pernah menemui soal ini atau yang seperti ini?

$\mathrm{S} 1$ : belum

P : apa kamu membaca soal sebelum mengerjakanya?

S1 : iya

$\mathrm{P}$ : setelah melihat soal, apa yang anda pikirkan dari soal ini?

S1 : bingung

$\mathrm{P}$ : apakah anda paham dengan soal ini?

$\mathrm{S} 1$ : belum

$\mathrm{P}$ : apakah anda mengalami kesulitan dalam memahami soal yang diberikan

S1 : iya

P : apa yang membuatmu kesulitan?

S1 : menetukan volume

$\mathrm{P}$ : bisakah mengerjakan soal tersebut langsung anda jawab tanpa berpikir panjang/lama?

$\mathrm{S} 1$ : belum bisa 
Hasil wawancara yang dilakukan dengan subjek 1 terlihat bahwa dalam menemukan penyelesaian dilakukan dengan membaca soal kemudian subjek mengaitkan soal dengan teori penyelesaian yang diajarkan. Pada saat itu subjek menyadari bahwa soal yang ia dapatkan berbeda dengan soal yang diberikan sebelumnya. Dalam kondisi ini subjek mengalami kesulitan dalam menyelesaikan soal yang diberikan oleh peneliti dan menyelesaikan semampunya. Sepertinya disini subjek 1 mulai memilih strategi yang bisa digunakan untuk membantu menyelesaikan permasalahan.

$\mathrm{P}$ : jika tidak, apa yang membuat anda kesulitan dalam menjawab soal ini?

$\mathrm{S} 1$ : mencari tinggi dan sisi miring

$\mathrm{P}$ : bagaimana anda mengatasi kesulitan yang anda alami?

$\mathrm{S} 1$ : belum tahu

P : bagaimana Strategi dalam mengerjakan/menyelesaikan soal ini?

S1 : tidak tahu

P : apakah anda kesulitan mencari strategi yang tepat untuk mengerjakan soal tersebut?

$\mathrm{S} 1$ : iya

$\mathrm{P}$ : jika iya, apa yang membuat anda kesulitan dalam memilih strategi untuk mengerjakan soal tersebut?

$\mathrm{S} 1$ :lupa rumus

Dari hasil wawancara terlihat subjek 1 mengalami kesulitan untuk memilih langkah-langkah dan strategi yang cocok untuk menyelesaikan masalah yang dialaminya. Sejauh ini yang dilakukan Subjek1 hanya sebatas menuliskan yang diketahui didalam soal, yang ditanyakan pada soal, kemudian ia mencoba menyelesaikan soal semampunya pada lembar jawaban. Pada kertas lain subjek mencoba alternative penyelesaian yang lain untuk menyelesaikan soal. Dalam proses ini peneliti dapat mengetahui bagaimanasubjek mengatasi kesulitan dalam menyelesaikan soal.

Dari semua pemaparan diatas, dapat disimpulkan bahwa subjek 1 dalam menyelesaikan soal penelitian ini sebagai berikut. Langkah-langkah yang subjek gunakan dalam menyelesaikan soal adalah membaca dan memahami, menggali serta menuliskan informasi yang dapat dimunculkan dari soal yang dilanjutkan memilih strategi (langkah ini tidak terlalu terlihat), kemudian mengerjakannya serta meneliti jawaban kembali dengan mengerjakan atau menghitungnya ulang. Kesulitan yang dialami subjek 1 yaitu subjek baru pertama menemui soal seperti yang diberikan peneliti, subjek masih kesulitan menentukan langkah-langkah dan strategi yang akan ia gunakan. Akhirnya langkah yang ia gunakan sesuai dengan langkah pemecahan masalah menurut Polya. Dalam proses menyelesaikan masalah, subjek 1 menggunakan beberapa strategi seperti memecah tujuan, membuat coretan dikertas, dan berpikir logis untuk membantu memudahkan dalam 
menyelesaikan masalah matematika yang diberikan.

\section{b) Subjek 2}

Dari hasil jawaban subjek 2, subjek menuliskan yang diketahui dari soal secara lengkap, kemudian menuliskan permasalahan yang ditanyakan dalam soal. Berikut penggalan jawaban subjek 2 pada lembar jawaban.

Dik: dianneter bola $=6 \mathrm{~cm}$
tinggi tabung $=9 \mathrm{~cm}$
Dit: Volume tahung?
Jawab:

Gambar4.3.Hasil Jawaban Subjek 2

Dari gambar 4.3, dapat dilihat subjek 2 didalam lembar jawabnya menuliskan semua yang telah diketahui pada soal yang ia dapatkan, dari membaca soal yang diberikan oleh peneliti. Hal ini menunjukkan bahwa subjek 2 telah membaca soal dengan seksama dan mampu menentukan hal yang diketahui dalam soal tersebut, maka subjek 2 siap untuk melanjutkan mengerjakan soal dan nantinya subjek 2 akan lebih mudah untuk menghubungkan fakta-fakta yang ada sehingga mampu mencari hal yang diperlukan untuk memecahkan masalah padasoal.

Dalam catatan lapangan terlihat bahwa dari pertama mendapat soal subjek 2 membaca soal yang ia selingi dengan menuliskan sesuatu pada lembar jawab dan menuliskan beberapa dilembar lain, ia juga terlihat sering memandangi lembar soal. Hal ini menunjukkan subjek 2 membaca soa lterlebih dahulu sambil memahami soal dan mulai menuliskan apa yang bisa didapat dari soal untuk membuat rencana penyelesaian, kemudian dapat menentukan hal-hal yang dibutuhkan dalam proses pemecahan masalah.

Hasil wawancara dengan subjek 2 juga mendukung apa yang peneliti paparkan diatas. Berikut beberapa penggalan wawancara yang peneliti lakukan.

$\mathrm{P}$ : apakah sudah pernah menemuisoal ini atau yang seperti ini?

S2 : tidak

P: apakah kamu membaca soal terlebih dahulu?

S2 : iya

$\mathrm{P}$ : setelah melihat soal, apa yang anda pikirkan dari soal ini?

S2 : bingung

P : apakah anda paham dengan soal ini?

S2 : tidak

P: apakah anda mengalami kesulitan dalam memahami soal yang diberikan?

S2 : iya

P: bisakah mengerjakan soal tersebut langsung anda jawab tanpa berpikir panjang/lama

$\mathrm{S} 2$ : tidak

Hasil wawancara yang dilakukan dengan subjek 2 terliha tbahwa dalam menemukan penyelesaian dilakukan dengan membaca soal, kemudian subjek 2 mengaitkan soal dengan teori penyelesaian yang telah diajarkan.Pada saat itu subjek 2 menyadari bahwa soal yang didapat berbeda dengan soal yang sering diberikan sebelumnya, dalam kondisi ini subjek 
mengalami kesulitan dalam menyelesaikan soal yang diberikan oleh peneliti dan menyelesaikannya semampunya.

P: jika tidak, apa yang membuat anda kesulitan dalam menjawab soal ini?

S2 : mencari tinggi tabung

$\mathrm{P}$ : bagaimana anda mengatasi kesulitan yang anda alami?

S2 : bingung(siswageleng-gelengkepala)

P: bagaimana langkah-langkah dalam mengerjakan soal ini?

S2: menulis yang diketahui,yang ditanyakan, menulis rumus tinggi, menulis

P : apakah anda mendapat kankesulitan saat memilih langkah untuk mengerjakan soal tersebut?

S2 : iya

$\mathrm{P}$ : apa langkah pertama yang dilakukan?

S2 : menulis rumus

$\mathrm{P} \quad$ : apakah anda punya cara lain yang lebih mudah untuk menyelesaikan soal ini?

S2 : tidak

$\mathrm{P}$ : bagaimana Strategi dalam mengerjakan/menyelesaikan soal ini?

S2 : tidak tahu

P : apakah anda kesulitan mencari strategi yang tepat untuk mengerjakan soal tersebut?

S2 : iya

$\mathrm{P}$ : jika iya, apa yang membuat anda kesulitan dalam memilih strategi untuk mengerjakan soal tersebut?

S2 : kurang tahu, lupa rumus
Dari hasil wawancara terlihat subjek 2 mengalami kesulitan untuk menentukan tinggi tabung. Sejauh ini yang dilakukan Subjek 2 menuliskan yang diketahui, yang ditanyakan, menulis rumus untuk mencari tinggi. Dari data yang didapat terlihat bahwa kesulitan yang dialami oleh subjek 2 yaitu karena ia kurang menguasai materi, ditandai dengan tidak ingat rumus yang digunakan untuk mengerjakan soal tersebut. Kemudian ia mencoba menyelesaikan soal semampunya pada lembar jawabannya. Pada kertas lain subjek mencoba alternatif penyelesaian yang lain untuk menyelesaikan soal. Dalam proses ini peneliti dapat mengetahui bagaimana subjek mengatasi kesulitan dalam penyelesaan soal.

Kesulitan subjek 2 untuk menentukan tinggi tabung terlihat dari hasil jawaban, bahwa subjek 2 masih belum menguasai rumus tabung dan bola. Hal ini juga menunjukkan subjek 2 menentukan langkah untuk menyelesaikan soal yang diberikan. Subjek 2 menggunakan keterampilan dan pengetahuan matematikanya untuk menemukan langkah yang tepat. Subjek 2 terlihat membaca soal berulang kali untuk menemukan maksud dan alternatif penyelesaian yang lebih mudah.

Dari catatan lapangan setelah menemukan penyelesaian, subjek 2 meneliti kembali jawabannya untuk memastikan bila jawaban sudah tidak ada kekeliruan. Ternyata subjek 2 memeriksa kembali jawabannya sebelum dikumpulkan kembali kepada peneliti. Wawancara 
dengan subjek 2 menguatkan yang telah dipaparkan oleh peneliti.

P : Ketika sudah ditemukan jawabannya, apa yang selanjutnya anda lakukan?

S2 : Meneliti kembali

$\mathrm{P}$ : Apakah anda menelusuri kembali jawaban yang anda peroleh?

S2 : Iya

$\mathrm{P}$ : Jika iya, apa yang anda lakukan pada hasil pekerjaan?

S2 : Mengulang penjumlahan dan perkalian

Dari penggalan wawancara diatas, didapat subjek 2 menelusuri kembali hasil pekerjaannya. Subjek juga terlihat bisa menghubungkan beberapa fakta yang ada dan mencari jari-jari lingkaran, mencari tinggi tabung, sebagai tujuannya sebelum menuju ketujuan utamanya mencari volume bola. Subjek 2 juga meneliti kembali jawaban dengan cara melihat jawabannya sebelum diserahkan kepada peneliti.

Dari semua pemaparan diatas, dapat disimpulkan bahwa subjek 2 dalam menyelesaikan soal penelitian ini sebagai berikut. Langkah-langkah yang subjek gunakan dalam menyelesaikan soal adalah membaca dan memahami, menggali serta menuliskan informasi yang dapat dimunculkan dari soal yang dilanjutkan memilih strategi (langkah ini tidak terlalu terlihat), kemudian mengerjakannya serta meneliti jawaban kembali dengan mengerjakan atau menghitungnya ulang. Kesulitan yang dialami subjek 2 yaitu subjek baru pertama menemui soal seperti yang diberikan peneliti, kesulitan dalam mencari tinggi tabung subjek masih kesulitan menentukan langkah-langkah dan strategi yang akan ia gunakan. Akhirnya yang ia gunakan yaitu membaca soal dan memahaminya, menulis data yang diketahui didalam soal, membuat coretan dilembar lain, menentukan rencana penyelesaian, menyelesaikan masalah sesuai dengan rencana, dan terakhir ia meneliti kembali hasil pekerjaannya.

\section{c) Subjek 3}

Dari hasil jawaban subjek 3, subjek menuliskan yang diketahui dari soal, kemudian menuliskan yang ditanyakan dalam soal. Berikut penggalan jawaban subjek 3 pada lembar jawab.

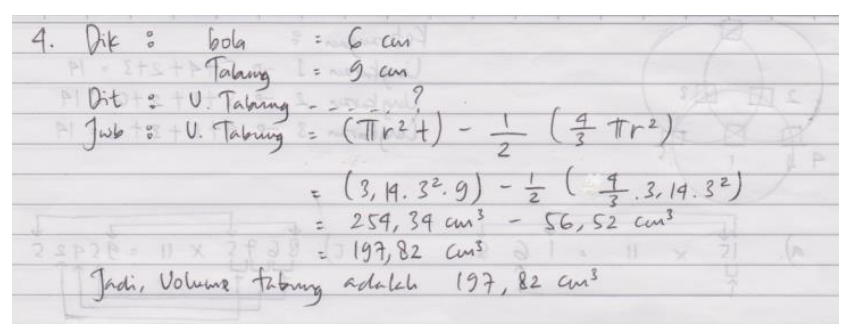

Gambar 4.4. Hasil Jawaban Subjek 3

Dari gambar 4.4 dapat dilihat subjek 3 didalam lembar soal ia menuliskan ukuran yang terdapat didalam soal,hal ini dimaksudkan untuk memperjelasdan mempermudah saat mengerjakan soal nantinya. Selanjutnya dapat dilihat dilembar jawab, subjek 3 menuliskan yang diketahui pada soal berupa luas bangun keseluruhan. Hal ini berarti subjek telah membaca soal dan menentukan apa yang diketahui dalam soal tersebut, dengan demikian subjek terlihat sudah mengetahui apa yang harus dilakukan untuk melanjutkan mengerjakan soal yang diberikan. 
Dalam catatan lapangan terlihat bahwa dari awal pertama mendapat soal subjek 3 membaca soal terlebih dahulu yang ia selingi dengan menuliskan sesuatu pada lembar jawab dan menuliskan beberapa dilembar lain, subjek 3 juga terlihat sering memandangi lembar soal. Hal ini menunjukkan subjek 3 membaca soal terlebih dahulu sambil memahami soal dan mulai menuliskan apa yang bisa didapat dari soal untuk membuat rencana penyelesaian, kemudian dapat menentukan hal-hal yang dibutuhkan dalam proses pemecahan masalah.

Hasil wawancara dengan subjek 3 juga mendukung apa yang peneliti paparkan diatas. Berikut beberapa penggalan wawancara yang peneliti lakukan.

$\mathrm{P}$ : apakah sudah pernah menemui soal ini atau yang seperti ini?

S3 : belum

P : apakah hal pertama yang anda lakukan?

S3 : membaca soal

P : Setelah melihat soal, apa yang anda pikirkan dari soal ini?

S3 : Bingung

P : Apakah anda paham dengan soal ini?

S3 : Tidak

P: Apakah anda mengalami kesulitan dalam memahami soal yang diberikan?

S3 : Iya

P: Bisakah mengerjakan soal tersebut langsung anda jawab tanpa berpikir panjang/lama?

S3 : Tidak
Hasil wawancara dengan subjek 3 terlihat dalam menemukan langkah penyelesaian dilakukan dengan membaca soal, kemudian subjek 3 mengaitkan soal denganteori penyelesaian yang telah dipelajari sebelumnya. Pada saat itu subjek mengetahui bahwa soal yang didapatnya berbeda dengan soal yang telah dipelajarinya. Dalam kondisi ini subjek mengalami kesulitan dalam menyelesaikan soal yang diberikan oleh peneliti dan menyelesaikan semampunya. Hasil wawancara dengan subjek 3 dibawah ini menunjukkan kesulitan yang dialami subjek.

P : jika tidak, apa yang membuat anda kesulitan dalam menjawab soal ini?

S3 : mencari tinggi tabung

$\mathrm{P}$ : bagaimana anda mengatasi kesulitan yang anda alami?

S3 : mengingat-ingat kembali

$\mathrm{P}$ : apa yang di ingat-ingat?

S3 : rumus yang di cari

$\mathrm{P}$ : bagaimana langkah-langkah dalam mengerjakan soal ini?

S3 : mencari tinggi tabung,

P : apakah anda mendapatkan kesulitan saat memilih langkah untuk mengerjakan soal tersebut?

S3 : iya

$\mathrm{P}$ : apa langkah pertama yang dilakukan?

S3 : mencari tinggi

P : apakah anda punya cara lain yang lebih mudah untuk menyelesaikan soal ini?

S3 : tidak

P : bagaimana Strategi dalam mengerjakan/menyelesaikan soal ini? S3 : tidak tahu 
P : apakah anda kesulitan mencari strategi yang tepat untuk mengerjakan soal tersebut?

S3 : iya

$\mathrm{P}$ : jika iya, apa yang membuat anda kesulitan dalam memilih strategi untuk mengerjakansoal tersebut?

S3 : mencari tinggi

Dari hasil wawancara terlihat subjek 3 mengalami kesulitan untuk mencari tinggi tabung. Sejauh ini yang dilakukan Subjek 3 hanya sebatas menuliskan yang diketahui didalam soal, yang ditanyakan pada soal, kemudian ia mencoba menghitung yang ia dapatkan, kemudian ia mencoba menyelesaikan soal semampunya pada lembar jawaban. Pada kertas lain subjek 3 mencoba alternatif penyelesaian yang lain untuk menyelesaikan soal. Dalam proses ini peneliti dapat mengetahui bagaimana subjek mengatasi kesulitan dalam penyelesaian soal.

Subjek 3 telah mencoba menghitung data yang diperoleh dari soal. Terlihat juga subjek 3 menuliskan dilembar coretannya meliputi rumus tabung dan rumus bola. Hal ini menandakan bahwa subjek 3 sudah mengetahui maksud dari soal, dengan mencoba menyelesaikannya. Tetapi mengalami kesulitan, sehingga terhambat dalam menyelesaikan soal. Pernyataan ini dibuktikan dengan hasil penyelesaian subjek 3 didalam lembar jawaban.

Dari catatan lapangan didapat subjek 3 sebelum mengumpulkan ia sempat melihat kembali soalnya beberapa saat. Ternyata subjek 3 sudah memeriksa kembali jawabannya sebelum akhirnya dikumpulkan, selanjutnya dari wawancara juga menguatkan paparan di atas.

$\mathrm{P}$ : Ketika sudah ditemukan jawabannya, apa yang selanjutnya anda lakukan?

S3 : Meneliti kembali

$\mathrm{P}$ :Apakah anda menelusuri kembali jawaban yang anda peroleh?

S3 : Ya

P : Jika iya, apa yang anda lakukan pada hasil pekerjaan?

S3 : Mengulang rumus-rumus yang tadi

Dari penggalan wawancara di atas, didapat subjek 3 meneliti pekerjaannya sebelum diserahkan kembali kepada peneliti. Subjek juga terlihat mampu menghubungkan beberapa fakta yang ada menuju ketujuan utamanya mencari volume tabung. Kemudian subjek 3 juga meneliti kembali jawaban dengan cara melihat jawabannya sebelum diserahkan kepada peneliti.

Dari semua pemaparan diatas, dapat disimpulkan bahwa subjek 3 dalam menyelesaikan soal penelitian ini sebagai berikut. Langkah-langkah yang subjek gunakan dalam menyelesaikan soal adalah membaca dan memahami, menggali serta menuliskan informasi yang dapat dimunculkan dari soal yang dilanjutkan memilih strategi, kemudian mengerjakannya serta meneliti kembali jawaban dengan mengerjakan atau menghitungnya ulang. Kesulitan yang dialami subjek 3 yaitu subjek baru pertama menemui soal seperti yang diberikan peneliti, kemudian subjek 3 juga masih 
kesulitan untuk mencari tinggi tabung, subjek masih kesulitan menentukan langkah-langkah dan strategi yang akan ia gunakan bila soal yang diberikan berbeda dari soal yang biasa diberikan. Akhirnya yang ia gunakan yaitu membaca soal dan memahaminya, menulis data yang diketahui didalam soal, membuat coretan dilembar lain, menentukan rencana penyelesaian, menyelesaikan masalah sesuai dengan rencana, dan terakhir ia meneliti kembali hasil pekerjaannya.

\section{Penyajian Data}

\section{a) Subjek 1}

Kesulitan yang dialami subjek 1 yaitu subjek menyadari bahwa soal yang diberikan berbeda dari soal yang diberikan, subjek masih kesulitan menentukan langkah-langkah dan strategi yang akan ia gunakan.

Subjek 1 dalam megatasi kesulitan yang dialami dalam menyelesaikan soal menggunakan langkah yang pertama membaca dan memahami, menggali serta menuliskan informasi yang dapat dimunculkan dari soal yang dilanjutkan memilih strategi (langkah ini tidak terlalu terlihat), kemudian menyelelesaikan soal semampunya serta meneliti jawaban kembali dengan mengerjakan atau menghitungnya ulang. Langkah yang digunakan subjek 1 sesuai dengan langkah pemecahan masalah menurut Polya.

\section{b) Subjek 2}

Kesulitan yang dialami subjek 2 yaitu subjek baru pertama menemui soal seperti yang diberikan peneliti, kesulitan dalammenyelesaikan soal karena soal berbeda dari soal yang diajarkan, kesulitan dalam mencari tinggi, sisi miring.

Subjek 2 dalam menyelesaikan soal penelitian ini menggunakan langkahlangkah yaitu membaca dan memahami, menggali serta menuliskan informasi yang dapat dimunculkan, dilanjutkan memilih strategi, kemudian mengerjakannya serta meneliti jawaban kembali dengan mengerjakan atau menghitungnya ulang.

\section{c) Subjek 3}

Kesulitan yang dialami subjek 3 yaitu subjek baru pertama menemui soal seperti yang diberikan peneliti, kemudian subjek 3 juga masih kesulitan untuk mencari tinggi tabung, subjek masih kesulitan menentukan langkah- langkah dan strategi, bila soal yang diberikan berbeda dari soal yang biasa diberikan.

Subjek 3 dalam menyelesaikan soal penelitian menggunakan langkah- langkah yaitu membaca dan memahami, menggali serta menuliskan informasi yang dapat dimunculkan dari soal yang dilanjutkan memilih strategi, kemudian mengerjakannya serta meneliti kembali lembar jawabannya.

\section{Kesimpulan}

Berdasarkan reduksi data dan penyajian data, dapat disimpulkan bahwa kesulitan yang dialami mahasiswa calon guru Sekolah Dasar dalam pemecahan masalah matematika yaitu mahasiswa masih kesulitan untuk menyelesaikan soal, dimana soal yang diberikan berbeda dari soal yang biasa diberikan biasanya. Dapat dilihat dari penjelasan sebelumnya 
bahwa subjek disini mahasiswa PGSD semester V mayoritas mengalami kesulitan dalam menyelesaikan masalah matematika jika soal yang mereka dapat berbeda konsep dari soal yang biasa diajarkan selanjutya mahasiswa menyelesaikan soal semampunya. Dari hasil penelitian juga dapat dilihat bahwa langkah-langkah penyelesaian masalah yang digunakan subjek membaca soal dan memahami, menyusun rencana yang sesuai dengan permasalahan, menyelesaikan masalahsesuai dengan rencana yang telah ditentukan, dan memeriksa kembali jawaban sebelum akhirnya dikumpulkan kepada peneliti. Langkah-langkah yang digunakan subjek sesuai dengan pendapat Polya.

\section{A. Pembahasan}

Hasil dari analisis dan identifikasi kesulitan dan langkah-langkah serta strategi yang digunakan mahasiswa dalam menyelesaikan masalah matematika dalam hal ini soal penelitian, diperoleh data yang valid. Berikut ini merupakan rangkuman hasil analisisdan identifikasi kesulitan yang dialami mahasiswa dan langkah-langkah serta strategi yang digunakansiswa dari hasil jawaban, catatan lapangan, dan hasil wawancara dari subjek penelitian.

Kesulitan yang dialami mahasiswa dan langkah-langkah serta strategi pemecahan masalah yang digunakan semester $\mathrm{V}$ dalam menyelesaikan masalah matematika dalam hal ini soal penelitian adalah sebagai berikut:

1) Subjek menuliskan apa yang bisa didapatkan dari yang diketahui pada soal, secara keseluruhan, selanjutnya subjekjuga menuliskan yang ditanyakan didalam soal. Hal ini berarti subjek telah membaca terlebih dahulu, memahami soal dan memunculkan fakta dari soal yang ada sehingga mampu mencari apa yang dapat diketahui dari soal.

2) Ketika menerima soal, yang pertama subjek lakukan ialah membaca sebentar soal kemudian mulai mengerjakan dilembar jawab yang tersedia, selanjutnya terlihat membuka lembar coretan dan menuliskan sesuatu. Terlihat subjek membaca lembar soal, yang sepertinya ia mencari fakta-fakta yang nantinya akan ia gunakan dalam pengerjaan. Subjek melanjutkan menulis dilembar coretan dengan sesekali melihat soal, subjek mulai menghitung yang sudah dia dapatkan dari soal.

Dari hasil wawancara dengan subjek juga mendukung pemaparan diatas. Hasil wawancara dengan subjek terlihat bahwa langkah yang digunakan subjek dalam menyelesaikan soal penelitian adalah dengan membaca soal, kemudian subjek mengaitkan soal dengan teori penyelesaian yang diajarkan. Pada saat itu subjekmenyadaribahwasoalyang diberikan peneliti berbeda dengan soal yang diberikan. Dalam kondisi ini subjek mengalami kesulitan dalam menyelesaikan soal yang diberikan dan subjek menyelesaikan soal semampunya.

Dari hasil wawancara terlihat subjek mengalami kesulitan untuk mencari tinggi tabung. Sejauh ini yang 
dilakukan subjek hanya sebatas menuliskan yang diketahui didalam soal,yang ditanyakan pada soal, mencoba menghitung fakta yang diperoleh, kemudian subjek mencoba menyelesaikan soal semampunya pada lembar jawaban. Pada kertas lain subjek mencoba alternative peyelesaan yang lain untuk menyelesaikan soal. Dalam proses ini peneliti dapat mengetahui bagaimana subjek mengatasi kesulitan dalam menyelesaikan soal.

Dari penggalan wawancara, didapat subjek meneliti pekerjaannya sebelum diserahkan kembali kepada peneliti. Subjek juga terlihat mampu menghubungkan beberapa fakta yang ada dan mencari diameter bola, mencari tinggi tabung menuju ketujuan utamanya mencari volume tabung

Dari semua pemaparan diatas, dapat disimpulkan bahwa kesulitan dalam menyelesaikan masalah matematika yang dialami oleh subjek yaitu:

a) Subjek masih kesulitan untuk menyelesaikan soal apabila soal tersebut berbeda dari soal yang sering diajarkan sebelumnya

b) Subjek masih kesulitan mencari tinggi tabung

c) Subjek masih kesulitan menentukan langkah-langkah dan strategi yang akan ia gunakan.

Dalam penelitian ini didapatkan langkah-langkah penyelesaian yang digunakan oleh subjek dalam penyelesaian soal yaitu:

a) Membaca soal dan memahaminya.

b) menulis data yang diketahui didalam soal. c) membuat coretan di lembar lain.

d) Menentukan rencana penyelesaian.

e) menyelesaikan masalah sesuai dengan rencana, dan

f) meneliti kembali hasil pekerjaannya.

Dengan demikian dapat peneliti simpulkan bahwa mahasiswa calon guru Sekolah Dasar Universitas Majalengka dalam menyelesaikan masalah matematika cenderung menggunakan langkah-langkah pemecahan masalah yang sesuai dengan langkah-langkah seperti dikemukakan oleh Polya.

\section{KESIMPULAN DAN SARAN}

a. Kesimpulan

Berdasarkan hasil analisis data dari penelitian yang sudah dilakukan, maka diperoleh kesimpulan bahwa,

1. Faktor yang menyebabkan kesulitan mahasiswa yaitu (a) masih kurangnya pemahaman mahasiswa dengan materi yang diajarkan; (b) mahasiswa belum menguasai bangun ruang; (c) kurangnya daya ingat mahasiswa untuk mengingat kembali materi yang telah disampaikan.

2. Langkah-langkah penyelesaian yang ditemukan yaitu (a) membaca dan memahami; (b) menggali serta menuliskan informasi yang dapat dimunculkan dari soal; (c) memilih strategi penyelesaian; mengerjakannya serta meneliti kembali jawabannya.

b. Saran 
Saran yang dapat peneliti sampaikan berdasarkan dari hasil penelitian ini adalah sebagai berikut.

1. Mahasiswa harus diberikan latihanlatihan soal yang mempunyai bentuk berbeda-beda, dan siswa juga harus aktif mencari informasi supaya wawasan mahasiswa menjadi luas.

2. Dosen harus mendorong mahasiswa untuk bertanya apabila masih ada hal yang belum jelas.

3. Bagi calon peneliti yang lainnya agar dapat mengembangkan penelitian tentang kesulitan dalam pemecahan masalah matematika.

\section{DAFTAR PUSTAKA}

Ellison, J. G. 2009. Incresing Problem Solving Skill in Fifth Grade Advanced Mathematics Student. Journal of Curriculum and Instruction, 3(1): 1-17.

Hudoyo, H. 2001. Pengembangan Kurikulum dan Pembelajaran Matematika Malang. Fakultas MIPA Universitas Negeri Malang
Moleong, L. J. 2010. Metodologi Penelitian Kualitatif. Bandung:Remaja Rosdakarya

Polya, George. 1973. How to Solve It: a New Aspect of Mathematics Method 2nd Edition. New Jersey: Princeton University Press.

Ratnasari, Desi. 2014. Pengaruh Model Pembelajaran Generatif Terhadap Kemampuan Pemecahan Masalah Matematik Mahasiswa. Skripsi Sarjana. UIN Syarif Hidayatullah, Jakarta. Tidak dipublikasikan.

Ruseffend.1991. Pengantar kepada Membantu Guru Mengem-bangkan Kompetensinya dalam Pengajaran Matematika untuk Meningkatkan CBSA. Bandung: Tarsito

Siwono, Tatag Y. E. 2008.Model Pembelajaran Matematika Berbasis Pengajuan dan Pemecahan Masalah Untuk Meningkatkan Kemampuan Berpikir Kreatif. Unesa university Sugiman, Kusumah, \& Subanjar.2008. Pemecahan Masalah Matematis dalam Matematik Realistik. Bandung: Jurnal UPI. 
EduMa Vol. 7 No. 1 Juli 2018

ISSN $2086-3918$ 